\title{
Estimating Airline Employment: The Impact Of The 9-11 Terrorist Attacks
}

\section{David A. NewMyer, Robert W. Kaps, and Nathan L. Yukna}

Southern Illinois University Carbondale

\begin{abstract}
In the calendar year prior to the terrorist attacks of September 11, 2001, U. S. Airlines employed 732,049 people according to the Bureau of Transportation Statistics [BTS] of the U. S. Department of Transportation (Bureau of Transportation Statistics, U. S. Department of Transportation [BTS], 2001). Since the 9-11 attacks there have been numerous press reports concerning airline layoffs, especially at the "traditional," long-time airlines such as American, Delta, Northwest, United and US Airways. BTS figures also show that there has been a drop in U. S. Airline employment when comparing the figures at the end of the calendar year 2000 (732,049 employees) to the figures at the end of calendar year 2002 (642,797 employees) the first full year following the terrorist attacks (BTS, 2003). This change from 2000 to 2002 represents a total reduction of 89,252 employees. However, prior research by NewMyer, Kaps and Owens (2003) indicates that BTS figures do not necessarily represent the complete airline industry employment picture. Therefore, one key purpose of this research was to examine the scope of the post 9-11 attack airline employment change in light of all available sources. This first portion of the research compared a number of different data sources for airline employment data. A second purpose of the study will be to provide airline industry employment totals for both 2000 and 2002, if different from the BTS figures, and report those. Finally, the third purpose of the study was to report any variations from the overall airline industry trend. A literature review was used to complete this study. Sources used in this study included government documents, government web resources, published articles, aviation industry publications and various non-government web resources such as airline websites. Among the key conclusions of the study were the following: (1) Paralleling earlier studies, it was found that the BTS data underreported the total U. S. airline employment total by at least 61,005 employees in 2000 and 61,359 employees in 2002; (2) Utilizing a combination of BTS and World Aviation Directory (Jackman, F., 2000 and 2002) airline employment data, it was found that U. S. airline employment totals dropped by 88,898 employees or $12.5 \%$ when comparing the 2000 data with the 2002 data; (3) Low cost carriers including AirTran, Frontier, JetBlue and Southwest combined to add 9,440 employees in the same 2000 to 2002 period, an addition of 25.4 percent.
\end{abstract}

\section{INTRODUCTION}

In the Fall of 2001 and into the Spring of 2002, the headlines carried by major news publications screamed "layoffs" throughout the airline industry. As of the beginning of 2004, airlines in general began to recover with some airlines beginning to hire again, albeit against the backdrop of conflict in the Middle East and rising fuel prices. It now seems timely to look back to examine the extent of the airline employment loss since the Fall of 2001. This paper will focus only on the airlines, leaving post-9/11 employment trends in other aviation segments such as aerospace manufacturing to be examined elsewhere.
The current research is an outgrowth of prior aviation employment research, particularly NewMyer, D. A., Kaps, R. W., and Owens, R. T. C. (2003, July) Airline Employment Trends in the USA Since 1978. Proceedings of the Aviation Management Education and Research Conference and NewMyer, D. A., and Owens, R. T. C. (2003, October) Aviation Employment in the U. S.: A Review of Data Sources in Collegiate Aviation Review. Both of these documents identified the problem of the lack of a common, aviation industry-wide employment data source. Therefore, it is important for this paper to examine multiple sources of airline employment information to arrive at as accurate a depiction of airline employment data as possible. 
This paper will present airline employment figures from the Air Transport Association (ATA), the United States Department of Labor and the Bureau of Transportation Statistics of the US Department of Transportation, both as a whole, and by category of airline (major, national, large regional and medium regional). Other sources will also be examined such as the World Aviation Directory and airline websites. A total airline employment estimate will then be created from the various sources for both 2000 and 2002. This will allow a pre-9/11 and post9/11 comparison to be made. In examining the data, there will be comparisons drawn among known airline data sources and some general conclusions will be made related to the coverage of the various airline employment data sources and the impact of the $9 / 11$ attacks on the estimated airline employment totals.

\section{METHODOLOGY}

This paper is based on a literature review with a focus on a range of data sources related to airline employment. World events affecting the aviation industry, the availability of new aviation employment data sources, and the advent of increased access to employment data from on-line sources prompted the current study. Included in the review of literature were articles published in such scholarly journals as Collegiate Aviation Review and Journal of Aviation/Aerospace Education and Research, as well as information obtained from aviation industry publications such as Aviation Week and Space Technology and the World Aviation Directory. Information was also obtained from various government agencies related to aviation such as the US Department of Labor and the Bureau of Transportation Statistics of the US Department of Transportation. In addition, information about airline employment was obtained from aviation industry associations such as the Air Transport Association of America.

It is also important to mention the timeliness and validity of the data reported in each of the sources to be used in this study. Various concerns about the available airline employment data were identified in the research conducted by
NewMyer, Kaps and Owen (2003) and in the current research. These weaknesses include:

A. BTS data are reported only for those airlines who must report their employment data to the United States Department of Transportation. The nonreporting airlines are left out.

B. United States Department of Labor (USDOL) airline employment data is only available in an aggregate form and individual airline data are not available from USDOL.

C. Air Transport Association of America airline employment data are summaries of data provided for ATA member airlines only and are not inclusive of all airlines in the U. S. Also, ATA data are updated annually roughly parallel to the availability of data from the USDOT Form 41 reports that are also used by the BTS for their data. So, this source appears to duplicate the BTS data.

D. World Aviation Directory airline employment data are self-reported by each airline, are not mandated or regulated in any way, and are not necessarily updated by each airline in a timely fashion.

\section{HISTORICAL TRENDS}

Historical airline employment information from the years 1979 (deregulation took effect on October 24, 1978 and is assumed to not have an employment impact until 1979) to 2002 from the US Department of Transportation, Bureau of Transportation Statistics is presented in Table 1.

The key thing to note when reviewing the data in Table 1 is that, according to the US Department of Transportation, Bureau of Transportation Statistics, employment at major, national, and regional airlines has grown from 338,621 at the end of 1978 to 642,797 at the end of 2002. This is a near doubling (89.8\%) of airline employees in the US in this period. It 
also represents an annual average airline employment growth rate of $4.05 \%$ per year.

When analyzing the data provided by the BTS, you can see a couple of interesting anomalies. There are definite dips in the overall airline employment information. For example, these declines occur in the years 1979 through 1983, 1990 to 1992 and, 2000 to 2002. Therefore, there has been at least one important economic or world event in the early part of each of these decades that has had a negative effect on airline employment.

Table 1. Airline Employment by Year Since Deregulation, Included Is Major, National, Large And Medium Regional

\begin{tabular}{|c|c|c|c|}
\hline Year & Employment & Year & Employment \\
\hline 2002 & 642,797 & 1989 & 555,714 \\
\hline 2001 & 653,488 & 1988 & 512,533 \\
\hline 2000 & 732,049 & 1987 & 483,117 \\
\hline 1999 & 725,660 & 1986 & 435,872 \\
\hline 1998 & 696,202 & 1985 & 376,233 \\
\hline 1997 & 656,243 & 1984 & 347,197 \\
\hline 1996 & 634,866 & 1983 & 322.570 \\
\hline 1995 & 600,315 & 1982 & 329,059 \\
\hline 1994 & 585,427 & 1981 & 345,578 \\
\hline 1993 & 577,761 & 1980 & 354,264 \\
\hline 1992 & 569,005 & 1979 & 357,973 \\
\hline 1991 & 566,973 & 1978 & 338,261 \\
\hline 1990 & 588,926 & & \\
\hline \multicolumn{4}{|c|}{$\begin{array}{l}\text { SOURCE: Bureau of Transportation Statistics, United States Department of Transportation, Number of } \\
\text { Employees-Certificated Carriers 1978-2002. Retrieved April 4, } 2004 \text { from: } \\
\text { http://www.bts.gov/oai/ }\end{array}$} \\
\hline \multicolumn{3}{|c|}{$\begin{array}{l}\text { One such possibility for negative impact } \\
\text { would be an economic recession. According to } \\
\text { Hall, Feldstein, Frankel, et. al (2003): }\end{array}$} & $\begin{array}{l}\text { recessions are brief and they have been rare } \\
\text { in recent decades. }\end{array}$ \\
\hline & $\begin{array}{l}\text { significant } \\
\text { ross the econom } \\
\text { onths, visible in } \\
\text { yment, real inc } \\
\text { ales. A recessic } \\
\text { nomy reaches } \\
\text { s the economy r } \\
\text { trough and } \\
\text { expansion. Exp } \\
\text { of the econo }\end{array}$ & & $\begin{array}{l}\text { This is particularly helpful when looking at } \\
\text { some of the major events that have happened in } \\
\text { the past twenty years. For example, when the } \\
\text { recessions of the early 1980s and 1990 happened } \\
\text { (Federal Aviation Administration, 2003, IV-4) it } \\
\text { can be seen in Table } 1 \text { that airlines in general } \\
\text { experienced a small contraction in employment } \\
\text { during these same periods. It is interesting to } \\
\text { note, however, that regional airlines experienced } \\
\text { growth during the early 1990's (BTS, 1992). } \\
\text { The Gulf War is another example of a major } \\
\text { event that affected airline employment. }\end{array}$ \\
\hline
\end{tabular}


According to Gulf War chronology (WGBH Boston, n.d.) the first attack against Iraq was on January 17, 1991. During 1991, the major and national air carriers were in a brief decline in regards to employment. As for large and medium regional carriers, this was a substantial growth year. For example, in 1991, medium regional carriers employed 612 and 8,162 for large regional air carriers (BTS, 1992). In 1992, the employees of these two carrier groups were 2,345 and 9,610, respectively (BTS, 1993). When analyzing this further you can see that the employment growth rate during the time of the Gulf War for the medium regional segment of the air carrier industry was $283.1 \%$. For large regional air carriers the growth rate during the same period was $17.4 \%$. (BTS, 1993). Therefore, the regional airline employment growth that many such airlines experienced during the early part of the current decade, in spite of the poor economy and negative world events, was paralleled in the early 1990's during similar difficult times.

\section{US DEPARTMENT OF LABOR DATA}

An authoritative source of information on employment in the U. S. is the United States Department of Labor (USDOL). The USDOL classifies industries using the Standard Industrial Classification (SIC). SIC Group 45 is "Transportation by Air." This group includes "establishments engaged in furnishing domestic and foreign transportation by air and also those operating airports and flying fields and furnishing terminal services." (Office of Management and Budget, 1987, p. 277) The Department of Labor has recently adopted a new classification system called the North American Industry Classification System or NAICS (United States Department of Labor [USDOL], 2004). The NAICS is described by USDOL as a "clean slate" revision of the system used to classify employment establishments by industry type. Unlike previous SIC revisions, the NAICS changes are fundamental changes in the categories. The notice making NAICS effective in the U. S. was issued in April 1997 and the first NAICS U. S. manual was published in mid1998. (USDOL, 2004). While the NAICS is currently being implemented, the new classification system does not affect the statistics reported in this paper. The Department of Labor states that there were 1,251,430 people employed in the Transportation by Air group, SIC Code 45, as of March 1, 2003. (US Department of Labor, 2003). When collecting the data from the Department of Labor, either seasonal or non seasonal data can be used. The non seasonal adjustment numbers are reported here.

The SIC then narrows the "transportation by air” group further into sub-groups. For example, Major group 45 (Transportation by Air), Industry group Number 1, (451) is air transportation, scheduled, and air courier services. This group employs a total of 970,900 people. Another important subcategory of the 451 group is 4512 or 4513 (4512 is air transportation, scheduled). The 4512 industry group includes all companies that furnish air transportation over regular routes and on regular schedules. This industry classification includes air cargo carriers and air passenger carriers, (both must be scheduled). A total of 508,700 were employed in this group as of April 4, 2003 (USDOL, 2003). What is important to note about the USDOL data is that detailed information about categories of airlines (such as majors, nationals or regionals) is not available since the data are aggregated by industry and not company. 
Table 2. US Department Of Labor Employment Data for Industry Group 45: “Transportation By Air" (All Employees, Thousands)

\begin{tabular}{|l|l|l|l|l|l|}
\hline Year & Total & $\begin{array}{l}\text { Air Transportation } \\
\text { Scheduled and Air } \\
\text { Courier Services }\end{array}$ & $\begin{array}{l}\text { Air Transportation } \\
\text { Scheduled* }\end{array}$ & \multicolumn{2}{|l|}{$\begin{array}{l}\text { 2001 National Industry } \\
\text { Specific Occupation \& } \\
\text { Wage Estimates (new) }\end{array}$} \\
\hline SIC (old) & 45 & 451 & 4512 & 45 & $1,251,430$ \\
\hline & & & & 451 & $1,062,490$ \\
\hline 2000 & $1,279.9$ & $1,085.2$ & 582.5 & 4512 & Not Reported \\
\hline 2001 & $1,266.0$ & $1,070.3$ & 581.2 & 458 & 141,140 \\
\hline 2002 & $1,161.4$ & 970.9 & 508.7 & & \\
\hline
\end{tabular}

SOURCE: US Department of Labor, Bureau of Labor Statistics, $2003 * 4512$ is a sub-category of 451.

\section{ATA DATA}

Air Transport Association of America (ATA), the association that represents larger airlines operating in North America (including Canada), made this statement in their 2002 Annual Report: "One of the unfortunate outcomes of the terrorist attacks is that most airlines had to reduce their workforces. Airlines initially announced layoffs and furloughs of roughly 100,000 employees.” (Air Transport
Association of American [ATA], 2003) Yet, these layoffs were not reflected in the ATA's own airline employment data. In 2000 this number was 625,739 and in 2002 this number was 601,356, reflecting a decline far less than 100,000 employees. (ATA, 2001 and 2003) It is important to note that ATA airline employment numbers only include employment for ATA member airlines and include no data for most cargo and regional airlines.

Table 3. Air Transport Association Total Employees (Members)

$\begin{array}{ll}\text { Year } & \text { Total } \\ 2002 & 601,356 \\ 2001 & 624,197 \\ 2000 & 625,739 \\ 1999 & 609,347 \\ 1998 & 575,536 \\ 1997 & 545,926\end{array}$

SOURCE: Air Transport Association Annual Reports (1998-2003).

\section{BTS DATA}

The airline employment data set consists of cargo carriers, and passenger carriers. There are four types of passenger carriers. These types are Major, National, Large Regional and Medium Regional. (See Table 4) The USDOT reporting requirements for airlines categorize them into the above categories based on annual gross revenues, with any airline at $\$ 1.0$ billion or more in annual revenues being classified as a Major, with $\$ 100$ million to $\$ 1.0$ billion classified as a National while Large Regionals are at $\$ 10$ million to $\$ 100$ million and Medium Regionals are those below $\$ 10$ million. (Wells, 1999) 
Another difference in these types of air carriers is the type of airplane they operate (by aircraft seating capacity) and also if they report to the DOT on Form 41. Form 41 is a

Table 4. Bureau of Transportation Statistics By Group

Year 1998

1999

Majors

623,389

650,267

59,414

66,368

6,687

2,338

1,928

696,202

725,660

Total
Department of Transportation form which air carriers that operate aircraft with over 60 seats must submit on a monthly basis.

SOURCE: US Department of Transportation, Bureau of Transportation Statistics, Number of employeesCertificated carriers 1998-2002. Retrieved April 4, 2004 from http://www.bts.gov/oai/

The data that is collected is both financial and operational and is reported to the Bureau of Transportation Statistics (BTS). Form 298 (c) is the same as Form 41 except it is for air carriers operating under Part 135 and that have aircraft with 10 seats or less and this data is reported to BTS on a quarterly basis. (Federal Aviation Administration, 2003, p. IV-1)

The recent trends the BTS data depicted in Table 4 show us that all of the airlines categories have declined in employment when comparing 2000 and 2002 figures. However, two categories of 2002 data, nationals and large regionals, had already started to rebound from 2001 figures while majors and medium regionals continued to drop in 2002. This is a bit misleading due to the fact that several airlines have been known to grow to the point where they have "jumped" from one category to another. What was particularly confusing, however, is that the number of regional airlines actually reporting employment data to BTS has dropped from a total of eighteen large regionals that reported to the DOT in 1997 to ten large regionals reporting in 2001. This segment has seen its employment total, as reported in Table 4, dropped from 11,471 to 3,285 (-71.4\%). This shows that there is a problem with the employment reporting aspect of large regional air carriers. As for medium regionals, the past five year trend line in employment for this segment is $-40.2 \%$. This is partially due to the fact that there were sixteen carriers reporting in 1999 and now there are eleven. Once again, this shows the disparity of which carriers report and how they report their information to the BTS. Comparing the figures shown in Table 4, it can be seen that the majors and national groups have seen varying declines in employment in the past five years. The majors reached a peak of 672,294 in 2000 and dropped by 86,404 jobs by 2002, or a drop of 12.9 percent. The nationals reached their peak in 1999 at 66,368 and declined to $41,865(-36.9 \%)$ but rebounded to 52,470 by $2002(-20.9 \%)$.

\section{WORLD AVIATION DIRECTORY (WAD) DATA}

The Summer 2004 Edition World Aviation Directory (Jackman, F. [Ed]) data show what a problem there is in collecting accurate employment data. When analyzing the BTS data, it was obvious that there were some key carriers that had not reported their data to BTS and that regional airlines fluctuated widely in reporting employment data. The procedure used to verify the BTS data was to simply collect 
airline employment data from the World Aviation Directory by cross checking the BTS data by airline with the employment information contained in the airline employment listings in the WAD. Any airline not reported in the BTS data was recorded along with their employment number. A key characteristic of the WAD is that it is a voluntary, (not regulated), secondary source data set. That is, the WAD airline employment data are not necessarily updated regularly by each airline. The World Aviation Directory is a commercially published document with no government regulatory authority supporting it (as is the case with BTS data). This collection of data (See Table 5) showed that there were approximately 65 companies that were not reporting their statistics to the BTS. These companies accounted for a total of 57,348 employees at companies classified as major, national, large regional and medium regional airlines. This is a total of $10.07 \%$ of the total airline employment represented in BTS figures. Also, some of the companies listed in the WAD figures are quite small, or, may be non-existent. But, the key thing is that the BTS figures are missing sizeable employment numbers from companies that are not listed as reporting these data to BTS. For example, if one adds the WAD figure from Table $5(57,348)$ to the BTS figure for 2002 (642,797), the US airline employment total is 700,145 .

\section{ANALYSIS}

The Airline Transport Association of America says that during the 50 day Gulf War there were 25,000 jobs eliminated and the industry lost \$13 Billion. (ATA, 2003a). ATA has estimated that since $9 / 11$ there has been $\$ 18$ billion lost, and 100,000 job losses (ATA, 2003a and 2003b). There has been a loss of over 460,000 jobs since 9/11 in Tourism and Travel (ATA 2003a). In February 2003 airline fuel prices reached $\$ 1.20$ per gallon, representing a $108 \%$ increase over the previous year. Bookings for domestic travel are down more than 20\%, Atlantic down 40\%, Latin more than $15 \%$ and Pacific more than 30\%. (This was before SARS). (ATA, 2003a)

The composite airline employment data compiled in this paper show a slightly more optimistic picture of airline employment since the 9/11 attacks than what the ATA describes. For example, combining the BTS data for the end of calendar year 2000 with the World Aviation Directory data for the Spring of 2001 (Appendix 1) gives an immediate pre-9/11 attack airline employment figure of 793,054 employees. This number is composed of 756,150 employees at major and national airlines and 36,904 at regional airlines. Using the BTS/WAD combination to compile end of 2002 figures (Appendix 2), the total employment figure is 704,156, or a drop of 88,898 employees (somewhat less than the 100,000 mentioned by ATA and other sources) in two years. This represents an $11.2 \%$ drop in overall airline industry employment. What is interesting is that the majors and nationals together dropped by 94,379 employees to 661,771 employees ($12.5 \%$ ) but the regional airlines figures INCREASED by 5,481 to a total of 42,385 (an increase of $14.9 \%$ ). Table 6 summarizes the 2000-2002 changes.

As can be seen in the table above, the four low cost airlines depicted added a total of 9,440 employees in the 2000 to 2002 period, or a total increase of $25.4 \%$ within these four carriers. Of course, these airlines are not global carriers and are not subject to many of the pressures that the major airlines face with regard to things like the SARS crisis. However, it is still key to point out that not all airline industry segments suffered a downturn in employment in the post-9/11 period. Another bright spot in the figures are the employment data for so-called "low cost airlines" as shown in Table 7 
Table 5. Major and National Airlines According To 2004 WAD

\begin{tabular}{|c|c|c|c|}
\hline Air Carrier & Employment & Sales Number & Type \\
\hline ABX Air Inc. & 7,400 & $3,074,252$ & Cargo \\
\hline Atlas Air, Inc. & 1,600 & NO SALES \# & Scheduled \& Cargo \\
\hline BAX Global & 10,100 & $1,900,000,000$ & Cargo \\
\hline Express One Intl. & 300 & $100,000,000$ & Charter Cargo \\
\hline Total & 19,400 & & \\
\hline \multicolumn{4}{|c|}{ Regional Airlines According to WAD } \\
\hline Air Cargo Carriers, Inc. & 140 & $17,000,000$ & Scheduled and Cargo \\
\hline Air Midwest, Inc. & 225 & NO SALES \# & Scheduled and Cargo \\
\hline Air Sunshine, Inc. & & NO \# & Scheduled \& Charter \\
\hline Airline of the Virgin Islands & 40 & NO SALES \# & Scheduled \& Charter \\
\hline Alaska Central Express & 60 & NO SALES \# & Cargo \\
\hline Alaska Juneau & & NO \# & \\
\hline Aeronautics & 70 & NO SALES \# & Scheduled \& Cargo \\
\hline Alaska Seaplane & & NO \# & \\
\hline Services, LLC & 7 & NO SALES \# & Scheduled \\
\hline *Allegheny Airlines, Inc. & 1,650 & NO SALES \# & Scheduled \& Cargo \\
\hline Aloha IslandAir, Inc. & 260 & NO SALES \# & Scheduled \& Charter \\
\hline Ameriflight Inc. & 650 & $65,000,000$ & Scheduled \& Cargo \\
\hline Arctic Circle Air Service, Inc. & 40 & $8,000,000$ & Scheduled \& Cargo \\
\hline Arctic Transportation Services & 65 & NO SALES \# & Domestic \& Intl. \\
\hline Aruba Intl. Airways & 120 & $82,000,000$ & Scheduled \\
\hline Astral Aviation Inc. & 400 & $289,940,000$ & Scheduled \& Charter \\
\hline **Atlantic Coast Airlines & 3,000 & $2,100,000$ & Scheduled \& Cargo \\
\hline Atlantic Airlines, Inc. & 17 & $2,500,000$ & Cargo \\
\hline Atlantis Airways & 15 & $13,000,000$ & Scheduled \& Charter \\
\hline AVI Inc. & 100 & NO SALES \# & Scheduled \& Charter \\
\hline Aviation Services Ltd. & 90 & NO SALES \# & Scheduled \& Cargo \\
\hline Baker Aviation Inc. & 34 & NO SALES \# & Scheduled \& Cargo \\
\hline Bellair, Inc. & 15 & NO SALES \# & Scheduled \& Cargo \\
\hline Bemidji Aviation Services Inc & & NO \# & Scheduled \& Charter \\
\hline Bering Air, Inc. & 85 & $9,000,000$ & Scheduled \& Charter \\
\hline Big Sky Airlines & 245 & $26,800,000$ & Scheduled \& Cargo \\
\hline Cape Smyth Air Service, Inc. & 105 & $12,000,000$ & Scheduled \& Cargo \\
\hline Casino Express, Inc. & 128 & $22,000,000$ & Scheduled \& Cargo \\
\hline CCAir, Inc. & 420 & $70,000,000$ & Scheduled \& Cargo \\
\hline Chalks Ocean Airways & 45 & NO SALES \# & Scheduled \& Charter \\
\hline Challenge Air Cargo & 800 & $131,500,000$ & Scheduled Seaplane \\
\hline Chautauqua Airlines, Inc. & 1,350 & $240,000,000$ & Cargo \\
\hline Chicago Express Airlines, Inc. & 680 & $35,000,000$ & Scheduled \& Charter \\
\hline Coastal Air Transport & 7 & 500,000 & Scheduled \& Charter \\
\hline Colgan Air, Inc. & 200 & $19,000,000$ & Scheduled \& Cargo \\
\hline Comair Inc. & & NO \# & Scheduled \\
\hline Commutair & 340 & $85,000,000$ & Scheduled \& Charter \\
\hline Corporate Airlines, Inc. & 287 & NO SALES \# & Scheduled \& Cargo \\
\hline East Coast Aviation Services & 43 & $15,000,000$ & Scheduled \\
\hline
\end{tabular}


Empire Airlines, Inc.

Era Aviation

Express Airlines I

Express Jet Airlines

Florida West Intl.Airways, Inc

40 Mile Air

Frontier Flying Service, Inc.

Grand Canyon Airlines, Inc.

Great Lakes Airlines

Gulf \& Caribbean Cargo, Inc.

Gulfstream Intl. Airlines, Inc.

Hooters Air

Hyannis Air Service, Inc.

Island Airlines, Inc

Island Express Airlines

Jim Air, Inc.

Kenmore Air Harbor, Inc.

Ketchikan Air Service, Inc.

LAB Flying Services, Inc.

Laker Airways (Bahamas) Ltd.

Larry's Flying Service, Inc.

M\&N Aviation, Inc.

Mesa Airlines, Inc.

New England Airlines, Inc.

Olson Air Service, Inc.

Ozark Air Lines

Pacific Wings

Peninsula Airways, Inc.

Piedmont Airlines, Inc.

ProAir, Inc.

PSA Airlines, Inc.

Salmon Air

Skagway Air Service, Inc.

SkyWest Airlines

Suburban Air Freight, Inc.

Sunshine Airlines, Inc.

Tanana Air Service

Trans North Aviation, Ltd.

Vieques Air Link, Inc.

Virgin Air

Warbelow's Air Ventures, Inc.

West Isle Air

Wright Air Service Inc.

Yute Air Alaska Inc.

2004 Regional Airline Total

2004 Major and National Total

Overall 2004 Total
185

1,024

2,300

5,500

90

25

95

50

900

15

550

500

75

33

8

65

3

75

86

60

30

4,000

15

19

70

55

350

1,750

400

1,670

12

5,772

30

30
18

18
20

20

53
11

65

26

30

180

37,948

19,400

57,348
18,000,000

NO SALES \#

NO SALES \#

980,500,000

125,000,000

NO SALES \#

$7,000,000$

$5,000,000$

132,000,000

NO SALES \#

100,000,000

NO \#

NO SALES \#

NO SALES \#

NO SALES \#

NO SALES \#

$1,000,000$

$10,000,000$

NO SALES \#

NO SALES \#

4,600,000

NO SALES \#

NO SALES \#

2,300,000

$7,000,000$

$5,000,000$

NO SALES \#

NO SALES \#

NO SALES \#

NO SALES \#

NO SALES \#

$1,700,000$

NO \#

774,218,000

NO \#

$5,200,000$

$1,500,000$

$3,000,000$

NO SALES \#

NO SALES \#

$6,500,000$

$1,200,000$

NO SALES \#

22,000,000
Scheduled

Scheduled \& Charter

Cargo

Scheduled \& Charter

Scheduled \& Charter

Scheduled \& Charter

Cargo

Scheduled \& Cargo

Scheduled \& Cargo

Scheduled \& Charter

Scheduled \& Charter

Scheduled \& Cargo

Scheduled

Scheduled \& Charter

Scheduled

Scheduled

Scheduled \& Cargo

Scheduled \& Charter

Scheduled \& Charter

Scheduled \& Charter

Scheduled \& Charter

Scheduled \& Charter

Scheduled \& Cargo

Scheduled

Scheduled \& Charter

Scheduled \& Charter

Scheduled

Scheduled \& Charter

Scheduled \& Cargo

Scheduled \& Cargo

Scheduled

Scheduled

Scheduled \& Charter

Scheduled

Scheduled

Cargo

Scheduled \& Charter

Scheduled

Scheduled \& Charter

Scheduled

Scheduled \& Charter

Cargo

Scheduled \& Charter

Scheduled \& Charter

Source: Jackman, F (Ed.) (2004), World Aviation Directory, Summer, 2004 Edition 
Table 6. Airline Change From 2000 To 2002

\begin{tabular}{|c|c|c|c|}
\hline & Major\& National & Regional & Total \\
\hline $\mathbf{2 0 0 0}$ & 756,150 & 36,904 & 793,054 \\
\hline $\mathbf{2 0 0 2}$ & 661,771 & 42,385 & 704,156 \\
\hline Change & $-94,379$ & $+5,481$ & 88,898 \\
\hline
\end{tabular}

Source: Bureau of Transportation Statistics and World Aviation Directory

Table 7. Employment at “Low Cost” Airlines, 2000-2002

\begin{tabular}{|l|l|l|l|l|l|}
\hline & AirTran & Frontier & JetBlue & Southwest & Total \\
\hline $\mathbf{2 0 0 0}$ & 4,035 & 2,317 & 1,158 & 29,688 & 37,198 \\
\hline $\mathbf{2 0 0 2}$ & 4,919 & 3,620 & $4,011^{*}$ & 34,088 & 46,638 \\
\hline Change & +889 & +1303 & $+2,853$ & $+4,400$ & 9,440 \\
\hline
\end{tabular}

*From JetBlue Airways 2003 annual report (no BTS figure reported).

All other figures: Bureau of Transportation Statistics

\section{CONCLUSION}

This research further verifies that airline employment data sources vary widely in terms of their coverage and total reported numbers. For example, airline employment numbers from the Air Transport Association of America and the Bureau of Transportation Statistics do not cover the regional airline portion of the airline industry. In the case of ATA, the reason is obvious: The ATA membership is all that is included in their employment data. In the case of BTS, the numbers are shown only for those airlines required to report data to BTS via Forms 41 or 298. In the instance of US Department of Labor data, it is difficult to determine what is included and what is not since detailed, airlineby-airline data are not published. Turning to the World Aviation Directory, it is possible to obtain an estimate of airline employment data for any airline not reported in the BTS or ATA data, but which might be listed in the WAD. In fact, using the data from the World Aviation Directory, it is clear that the employment levels in all airline categories are currently underreported in the available industry sources.
Most important is that the regional airline employment figure is grossly underreported in BTS data according to what was discovered in WAD literature review. Therefore, using the comprehensive, combined picture created by the BTS and the WAD data, one can reach a more complete and inclusive view of U. S. airline employment data. Any such combination of data sources must recognize the previouslystated limits of airline employment data sources, particularly the concerns about the reliability of the self-reported data contained in the World Aviation Directory airline employment figures. On the other hand, there is no comprehensive source of airline employment data that contains the figures of Form 41 and 298 reporting airlines and those of the airlines who do not report their employment data via these forms. Until that happens, such combinations of data sources will have to be used by researchers to reach an industry-wide view of airline employment numbers.

With regard to the impacts of the 9/11 attacks, the data revealed that the employment impacts fell heaviest on the major and national airlines. The 2000 to 2002 change in 
employment was a decline of $-12.5 \%$ for this segment. On the other hand, large and medium regional airlines grew by $14.9 \%$ and low cost airlines grew by $25.4 \%$ in the same period. While there is some good news in these data, the good news only applies to approximately ten percent of the industry working in the regional airlines and low cost carriers. The rest of the industry, as depicted by these data, is still suffering from a large decline in employment that occurred in a short period of time. As implied earlier, there have been large downturns in the airline industry and its employment in the past. Some have been as large or larger than the post-9/11 reductions in terms of total percentage change. But, a drop of over 88,000 employees ($11.2 \%$ ) in two years is still significant and will take a number of years to reverse.

\section{RECOMMENDATIONS}

As the researchers completed the work on this literature review, there were a number of recommendations for further research, analysis and industry practice that were uncovered:

1. With regard to airline employment data:

A. The Bureau of Transportation Statistics is encouraged to conduct a special study of airline employment data with these two goals in mind

(1) To arrive at a total airline industry employment number endorsed by the federal government that represents the entire industry; and,

(2) In the process of conducting this study, identify a "painless" method of airline employment data reporting for those cargo and regional airlines not now reporting their employment data to BTS.

B. Further research needs to be conducted into the number of people working in the air cargo and regional airline segments of the airline industry.
2. With regard to the uses of a comprehensive set of airline employment data:

A. A better understanding of the economic impact of the airline industry will be achieved if we all know just how big the industry is, how widespread it is, and how many employees there are in the industry; and,

B. Universities, colleges and aviation training companies that are in the business of preparing future aviators need to have a clear understanding of the breadth of the airline industry and its employment needs. A comprehensive set of airline employment data, particularly one that clearly depicts where regional airline jobs are located (since regionals can provide key entrylevel airline employment) would be very useful in their efforts. 


\section{REFERENCE LIST}

Airports Council International - North America (2002). The economic impact of U.S. airports 2002. Retrieved January 22, 2003, from http://www.aci-na.org.

Air Transport Association of America, Inc. (2001). 2000 Annual report. Washington, DC: Air Transport Association

Air Transport Association of America, Inc. (2002). 2001 Annual report. Washington, DC: Air Transport Association

Air Transport Association of America, Inc. (2003a). Airlines in crisis: The perfect economic storm. Washington, DC, Air Transport Association

Air Transport Association of America, Inc. (2003b). Airlines seeing war impacts. Retrieved on April 22, 2003 from http://www.airlines.org/

Air Transport Association of America, Inc. (2003c). 2002 Annual report. Washington, DC: Air Transport Association

Air Transport Association of America, Inc. (2004). 2003 Annual report .Retrieved April 24, 2004, from: http://www.airlines.org/econ/econ.aspx

Avjobs.com. (2003, May). The airline industry. Avjobs.com. Retrieved May 7, 2003, from: http://www.avjobs.com/careers/industry.asp

Bureau of Transportation Statistics, U. S. Department of Transportation (1979-2003). Number of employeesCertificated carriers, 1978-2002 Retrieved April 4, 2004 from: http://www.bts.gov/oai/

Bureau of Transportation Statistics, U. S. Department of Transportation (1992). Number of employeesCertificated carriers, 1991 Retrieved April 4, 2004 from: http://www.bts.gov/oai/employees/1991emp.html

Bureau of Transportation Statistics, U. S. Department of Transportation (1993). Number of employeesCertificated carriers, 1992 Retrieved April 4, 2004 from: http://www.bts.gov/oai/employees/1992emp.html

Bureau of Transportation Statistics, U. S. Department of Transportation (1999). Number of employeesCertificated carriers, 1998 Retrieved April 4, 2004 from: http://www.bts.gov/oai/employees/1998emp.html

Bureau of Transportation Statistics, U. S. Department of Transportation (2000). Number of employeesCertificated carriers, 1999 Retrieved April 4, 2004 from: http://www.bts.gov/oai/employees/1999emp.html

Bureau of Transportation Statistics, U. S. Department of Transportation (2001). Number of employeesCertificated carriers, 2000. Retrieved April 4, 2004 from:

http://www.bts.gov/oai/employees/2000emp.html 
Bureau of Transportation Statistics, U. S. Department of Transportation (2002). Number of employeesCertificated carriers 2001. Retrieved February 5, 2003 from: http://www.bts.gov/oai/employees/2001emp.html

Bureau of Transportation Statistics, U. S. Department of Transportation (2003). Number of employeesCertificated carriers, 2002 Retrieved April 4, 2004 from: http://www.bts.gov/oai/employees/2002emp.html

Federal Aviation Administration. (2003). FAA aerospace forecasts 2003-2014. Washington, DC: U.S. Government Printing Office.

Hall, R., Feldstein, M., Frankel, J., Gordon, R., Romer, C., Romer, D., et.al. (2003, April 10). The NBER's recession dating procedure. Retrieved May 7, 2003, from: http://www.nber.org/cycles/recessions.html

Hughes, D., Fiorino, \& F., Dennis, W. (2003). Airlines feel winds of war as financial storm rages [Electronic Version]. Aviation Week \& Space Technology. Retrieved May 7, 2003, from,: http://www.aviationnow.com/avnow/new/channel_awst_story

Jackman, F. (Ed). World aviation directory. (Spring / Summer2001). Major/national/regional air carrier data, Sec. A1. Washington DC, McGraw-Hill.

Jackman, F. (Ed). World aviation directory. (Fall 2002/ Winter2003). Major/national/regional air carrier data, Sec. A1. Washington DC, McGraw-Hill.

Jackman, F. (Ed). World aviation directory. (Summer2004). Major/national/regional air carrier data, Sec. A1. Washington DC, McGraw-Hill.

JetBlue Airways (2003). Annual report. Retrieved April 28, 2004 from: http://investor.jetblue.com/ireye/ir_site.zhtml?ticker=jblu\&script=1700

National Air Transport Association. (2000). Aviation businesses and the services they provide. Alexandria, VA.

NewMyer, D. A., Kaps, R. W. \& Owen, R. T. C (2003, July). Airline employment trends in the USA since 1978. Proceedings of the Aviation Management Education and Research Conference, Montreal: Concordia University, published on CDROM.

NewMyer, D. A., Kaps, R. W., \& Sharp, S. E. (1997, Spring). Aviation industry employment data estimates revisited. Journal of Aviation/Aerospace Education and Research 7, 3, Daytona Beach: Embry Riddle Aeronautical University

NewMyer, D.A, Owen, R.T., (2003). Aviation employment in the US: A review of data sources Collegiate Aviation Review 21, 1.

Office of Management and Budget. (1987). Standard industrial classification manual. Office of Management and Budget. (NTIS No. PB 87-100012).

Southwest Airlines (2003). Annual report. Retrieved May 12, 2003 from:

www.iflyswa.com/investor relations/ar2002.html 
United States Department of Labor. (2001). 2001 Bureau of labor statistics occupational employment statistics. Retrieved March 17, 2004, from: http://www.bls.gov/oes/2001.oesi3 458.htm.

United States Department of Labor. (2002). 2002 Bureau of labor statistics occupational employment statistics. Retrieved March 16, 2004, from: http://www.bls.gov/oes/2002/oes530000.htm

United States Department of Labor. (2003). 2003 Bureau of labor statistics for industry Retrieved April 4, 2004, from: http://www.bls.gov/.

United States Department of Labor (2004). North American industry classification system (NAICS) Retrieved July 18, 2004 from http://www.bls.gov/bls/naics.htm

U.S. Department of Transportation. (1998). How to become a certified carrier. Washington, DC: Air Carrier Fitness Division.

Wells, A. T. (1999). Air transportation: A management perspective (4 ${ }^{\text {th }}$ ed.). Belmont, CA: Wadsworth Publishing Company.

WGBH Boston (n.d.). Frontline: The gulf war: Chronology. (n.d). Retrieved May 7, 2003, from: http://www.pbs.org/wgbh/pages/frontline/gulf/cron/

Yergin, D., Vietor, R.K., Evans, P.C., (2000, November). Fettered flight: Globalization and the airline industry. Washington DC: Air Transport Association. 


\section{APPENDIX A}

Pre 9/11 Attacks

US Airline Employment Data

Major and National Airlines

Air Carrier

ABX AIR Inc

Air Transport

Air Wisconsin

Airtran

Alaska

Aloha

America West

American

American Eagle

American Trans Air

Arrow

Atlantic Southeast

Atlas Air

BAX Global

Challenge Air Cargo

Continental

Continental Express

Continental Micronesia

Delta

DHL Airways

Emery

Evergreen

Executive

Express One

Federal Express

Frontier

Gemini

Hawaiian

Horizon

Jet Blue

Kitty Hawk Air Cargo

Legend

Mesaba

Midway

Midwest Express

National

Northwest

Polar Air

Ryan

Southwest

Spirit

Sun Country

Trans States
Full-time

622
2,551
3,622
9,112
1,762
10,992
86,663
8,189
7,018
1,318

Part-Time Total

7900

650

2,861

4,035

$1,221 \quad 10,333$

$1,050 \quad 2,812$

$2,809 \quad 13,801$

$14,536 \quad 101,199$

$1,235 \quad 9,424$

$953 \quad 7,971$

$25 \quad 1,343$

9900

33

36,156

4,205

1,148

66,758

3,938

475

1,103

492

93,073

1,847

591

2,874

3,517

833

796

2,615

1,524

2,534

1,156

50,341

765

1,260

28,860

1,574

1,273
33

45,944

4,697

1,567

80,390

10000

5,029

504

1,475

563

146,444

2,317

591

3,435

4,142

1,158

796

$760 \quad 3,375$

$688 \quad 2,212$

$651 \quad 3,185$

$215 \quad 1,371$

$3,548 \quad 53,889$

765

$17 \quad 1,277$

$828 \quad 29,688$

$337 \quad 1,911$

$200 \quad 1,473$ 
Trans World

United

United Parcel

USA Jet

USAIR

Vanguard

World Airways

Total Major \& Nationals

$$
\begin{array}{r}
18,835 \\
90,398 \\
5,231 \\
530 \\
41,708 \\
804 \\
950 \\
\mathbf{6 0 0 , 0 4 6}
\end{array}
$$

\section{Regional Airlines}

Full-time

Part-time

Air Carrier

40 Mile Air

Air Cargo Carriers Inc

Air Midwest Inc

Air Sunshine

Airlines, Inc.

Airlines, Inc.

Airlines, Inc.

Airways, Inc.

Alaska Central Express

Alaska Juneau Aeronutics

Alaska Seaplane Sevices

Allegiany

Aloha IslandAir

Ameriflight

Amerijet

Ameristar

Arctic Circle Air Sevice

Arctic Transportation Service

Aruba Intl. Airways

Asia Pacific

Astral Aviation Inc.

Atlantic Airlines, Inc.

Atlantic Coast Airlines

Atlantic Coast Jet

Atlantic World Airlines

Austin Express

AVI Inc.

Aviation Services Ltd.

Baker Aviation Inc.

Bellair, Inc.

Bemidji Aviation

Bering Air, Inc.

Big Sky Airlines

Business Express

California Coastal Airways

Cape Smyth Air

Capital Cargo

Cargo, Inc.

Casino Express

CCAir, Inc.

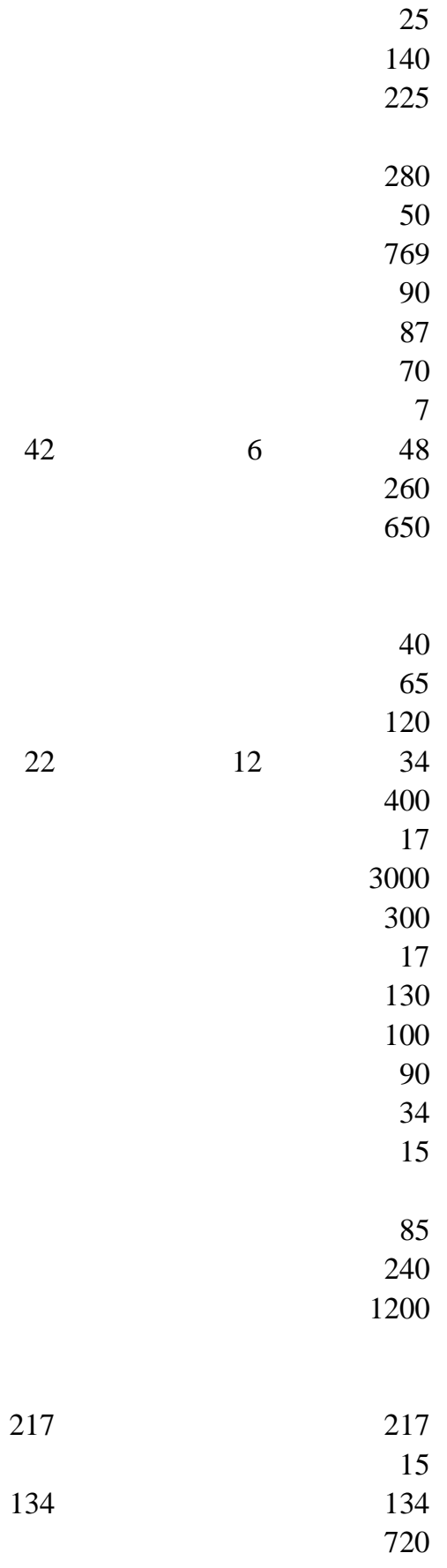


Chalks Ocean Airways

Challenge Air Cargo

800

Champion Air

Chautauqua Airlines, Inc.

Chicago Express

Coastal Air Transport

Colgan Air, Inc.

Comair Inc.

Commutair

Corporate Airlines, Inc.

Custom Air

East Coast Aviation

Empire Airlines, Inc.

Era Aviation

Express Airlines I

Expressnet

Falcon

Florida West

Florida West Intl.

Frontier Flying

Grand Canyon

Great Lakes Airlines

Gulf \& Caribbean

Gulfstream Intl.

Haines Airways

Hyannis Air Service, Inc.

Island Airlines, Inc

Island Express Airlines

Jim Air, Inc.

8

Kenmore Air Harbor, Inc.

Ketchikan Air Service, Inc.

LAB Flying Services, Inc.

Larry's Flying

Lynden

M\&N Aviation, Inc.

Mesa Airlines, Inc.

Miami Air

National Air Express

National Airlines

New England Airlines, Inc.

North American

Northern Air Cargo

Olson Air Service, Inc.

Ozark Air Lines

Pace

Pacific Island Aviation

Pacific Wings

Pan Am 
Planet

ProAir, Inc.

400

PSA Airlines, Inc.

1197

Redwing Airways

7

Reeve

79

89

Reliant

110

10

113

Salmon Air

Service, Inc.

Service, Inc.

Service, Inc.

Services Inc.

Services Ltd.

Sierra Pacific

30

Skagway Air Service, Inc.

SkyWest Airlines

Southcentreal Air

Southeast

Southern Air

Suburban Air Freight, Inc.

Sun Country

Sun Pacific

Sun World

1200

Sunshine Airlines, Inc.

Tanana Air Service

Tatonduk

Tradewinds

Trans Air

Trans Air Link

Trans North Aviation, Ltd.

Ventures, Inc.

Vieques Air Link, Inc.

Virgin Air

Warbelow's Air

West Isle Air

Wright Air Service Inc.

Yute Air Alaska Inc.

Zantop

Total Regionals

Total Majors and Nationals

00,046

Total Carriers

603,507

128,304 756,150

128,542 793,054

SOURCE: Jackman, F. (Ed.) World Aviation Directory (Spring/Summer 2001) 


\section{APPENDIX B}

Post 9/11 Attacks

US Airline Employment Data

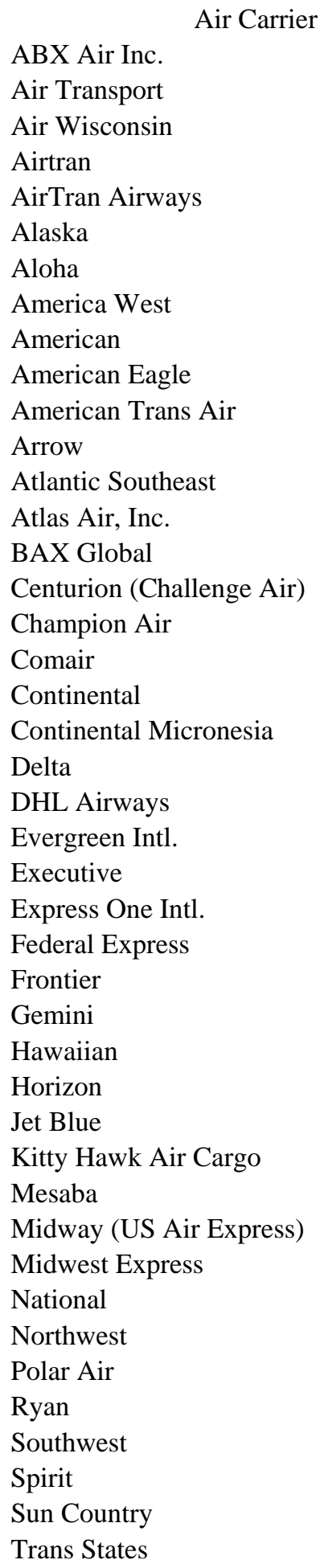

Major and National

Full-time Part-time

$\begin{array}{rr}560 & 26 \\ 2,837 & 288 \\ 4,500 & 419 \\ & \\ 9,521 & 1,302 \\ 1,755 & 996 \\ 10,285 & 2,585 \\ 88,256 & 13,857 \\ 7,349 & 1,016 \\ 6,477 & 354 \\ 1,000 & 30 \\ 4,907 & 349\end{array}$

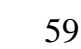

602

4,765

32,095

946

60,002

920

349

1,801

92,003

3,020

471

2,719

3,131

271

2,644

41

2,137

42,463

699

833

33,322

2,199

1,083
Total

7,900

586

3,125

4,919

4,000

10,823

2,751

12,870

102,113

8,365

6,831

1,030

5,256

1,600

9,900

60

781

5,379

40,244

1,358

68,703

936

550

2,346

300

139,342

3,620

471

3,223

3,687

271

3,446

41

2,684

44,361

767

840

34,088

2,579

1,211 
United

United Parcel

USA Jet

USAIR

Vanguard

World Airways

Total Major and Nationals

$\begin{array}{rrr}\mathbf{7 3 , 4 9 5} & 6,917 & 80,412 \\ 5,782 & 251 & 6,033 \\ 28,612 & 3,093 & 31,705 \\ 1,000 & 103 & 1,103 \\ & & \\ \mathbf{5 3 4 , 5 6 2} & \mathbf{1 0 3 , 7 9 8} & \mathbf{6 6 2 , 6 1 0}\end{array}$

\section{Regional Airlines According to WAD and BTS}

Atlantic Coast Airlines**

Allegheny Airlines, Inc*.

3,000

1,650

40 Mile Air

Air Cargo Carriers, Inc.

Air Sunshine, Inc.

Airline of the Virgin

Alaska Central Express

Alaska Juneau

Alaska Seaplane

Allegiant

133

133

Aloha IslandAir, Inc.

260

650

392

11

403

Amerijet

6

41

400

California Coastal Airways

105

Cape Smyth Air Service, Inc.

181

181

123

102

420

45 
Challenge Air Cargo

800

Chautauqua Airlines, Inc.

1,350

Chicago Express Airlines, Inc.

Coastal Air Transport

Colgan Air, Inc.

200

Comair Inc.

4,500

Commutair

340

Continental Express

5,100

Corporate Airlines, Inc.

Custom Air

East Coast Aviation

East Coast Aviation Services Ltd.

Empire Airlines, Inc.

Era Aviation

Express Airlines I

Expressnet

Falcon

Florida West

Florida West Intl. Airways, Inc.

Frontier Flying Service, Inc.

90

Grand Canyon

Grand Canyon Airlines, Inc.

50

Great Lakes Airlines

1,250

Gulf \& Caribbean Cargo, Inc.

Gulfstream Intl.

Gulfstream Intl. Airlines, Inc.

769

Hyannis Air Service, Inc.

500

Island Express Airlines

33

Islands, Ltd.

40

Jim Air, Inc.

Kalitta Air

246

8

Kenmore Air Harbor, Inc.

Ketchikan Air Service, Inc.

LAB Flying Services, Inc.

Laker Airways

Laker Airways (Bahamas) Ltd.

Larry's Flying

Larry's Flying Service, Inc.

Legend Airlines, Inc.

Lynden

M\&N Aviation, Inc.

Mesa Airlines, Inc.

Miami Air

1,450

Midway Airlines Corp.

New England Airlines, Inc.

1,000

North American

Northern Air Cargo

Olson Air Service, Inc.

Ozark Air Lines 
Pace

284

Pacific Island Aviation, Inc.

Pacific Wings

Pan Am

Peninsula Airways, Inc.

Piedmont Airlines, Inc.

1,750

Planet

149

149

Prestige Airways

150

ProAir, Inc.

400

PSA Airlines, Inc.

1,249

Redwing Airways, Inc.

Salmon Air

Services, LLC

Sierra Pacific

Skagway Air Service, Inc.

Sky King

SkyWest Airlines 5,000

Southeast

Southern Air

0

Suburban Air Freight, Inc.

Sun World

16

Sunshine Airlines, Inc.

Tanana Air Service

Tatonduk

Tradewinds

Trans Air Link

3155

Trans North Aviation, Ltd.

USA 3000

342

Ventures, Inc.

367

Vieques Air Link, Inc.

Virgin Air

Warbelow's Air

West Isle Air

Wright Air Service Inc.

Yute Air Alaska Inc.

Zantop

* Indicates that they are a part of US Airways / US Airways Express

** Indicates that they are a part of United Express / Delta Connection

Source: Jackman, F. (Ed.) World Aviation Directory Fall 2002/Winter 2003 and BTS 2002 